IP $\rightleftharpoons$ B

\title{
Response of Schizolobium parahyba seedlings to water stress
}

\author{
Daiane Marque Duarte ${ }^{1}\left[\begin{array}{l}(\mathbb{0}) \\ \text {, Gabriela Teodoro Rocha }\end{array}\right.$ \\ 1Universidade Federal de Uberlândia, Avenida João Naves de Ávila, 2121, CEP 38400-902, Santa Mônica, Uberlândia, MG, Brasil \\ ¿Universidade de Brasília, Campus Universitário Darcy Ribeiro, Gleba A, Asa Norte, CEP 70910-900, Brasília, DF, Brasil \\ ${ }^{3}$ Universidade Estadual de Goiás, Rodovia GO - 330, km 241, Anel Viário, CEP 75780-000, Ipameri, GO, Brasil
}

*Corresponding author:
fabricio.rodrigues@ueg.br
Index terms:
Guapuruvu
Water deficiency
Evapotranspiration
Termos para indexação:
Guapuruvu
Deficiência hídrica
Evapotranspiração

Received in 26/04/2018

Accepted in 20/02/2020

Published in 27/07/2020

\section{c) $(9)$}

\begin{abstract}
The objective of this study was to identify the response mechanisms to water stress Schizolobium parahyba Vell. Blake seedlings. At 90 days after emergency the plants were subjected to 10 days of water deficit, then they were irrigated with different percentages of evapotranspiration $(20,40,60,80$ and 100\%) for ten more days. In the initial stage of development, seedlings of Schizolobium parahyba were partially tolerant to the caused water deficit. They presented dehydration delay as a strategy, reducing growth in height, diameter and number of leaves and directing the production of photoassimilates for maintenance, with low transpiration rate.
\end{abstract}

\section{Resposta de mudas de Schizolobium parahyba ao estresse hídrico}

\begin{abstract}
Resumo - O objetivo deste trabalho foi identificar mecanismos de resposta ao estresse hídrico em mudas de Schizolobium parahyba Vell. Blake. Aos 90 dias após a emergência, as plantas foram submetidas a 10 dias de déficit hídrico, sendo irrigadas com diferentes porcentagens de evapotranspiração $(20,40,60,80$ e 100\%), por mais dez dias. No estágio inicial de desenvolvimento, as mudas de Schizolobium parahyba apresentaram tolerância parcial ao déficit hídrico causado e apresentaram um atraso na desidratação. Como estratégia de defesa, as plantas reduziram seu crescimento em altura, diâmetro e número de folhas, direcionando a produção de fotoassimilados para sua manutenção, com baixa taxa de transpiração.
\end{abstract}

The forest economic chain has been driven in the last few years by a great demand for wood and derivatives. It is necessary to improve the management strategies for maintenance of this chain, with new technologies for seedlings growth, so it would be possible to establish in the future commercial plantations with greater profitability (Rossa et al., 2013). Among several Brazilian species, we can highlight guapuruvu (Schizolobium parahyba (Vell.) Blake) a Fabaceae species from the Atlantic Forest. It can reach 10 to $20 \mathrm{~m}$ of height, with a high potential for timber production. Nevertheless, the seeds present dormancy mechanism, responsible for the longevity and perpetuation of the species over time (Sousa et al., 2005).

The wood is a promising source for paper pulp, providing paper with good resistance, with white straw color, yellowish or pinkish nuances, slightly shiny, and considered light, with a specific mass ranging from 0.24 to $0.40 \mathrm{~g} \mathrm{~cm}^{-3}$ (Nisgoski et al., 2012). When treated under pressure it dries easily, but can harden superficially under drastic conditions, which makes it suitable for the manufacture of wooden furniture, crates, liner panels for 
ceiling, canoes, aeromodelism objects, matchsticks and pencils (Carvalho, 2005). It is also used in the production of wood plates and panels (Bortoletto Júnior \& Belini, 2002). In addition, it is suitable for the recovery of degraded areas, with potential for management of wood production, without harming the environment or wood quality (Athanázio-Heliodoro et al., 2018).

There are several resources that are essential for plant production, with water being the most abundant and the most limiting. Approximately $35 \%$ of the terrestrial surface is considered arid or semi-arid and does not present adequate water supply for most cultivated species (Díaz-López et al., 2012). The current forecasts indicate global warming and an increase in the number of drought periods in many regions of the world, including Brazil (Guedes \& Costa, 2017). Thus, as water resources become scarce, the identification or knowledge of mechanisms that make the plants tolerant to the water deficit becomes a priority, for maintaining productivity.

Through adjustments that may contribute to a better adaptation of plants to their environment, most species have developed complex adaptive mechanisms to minimize the effects of water stress, where these conditions predominate (Ramegowda \& Senthil-Kumarb, 2015). The most common is the osmotic adjustment, which is usually accompanied by the absorption of inorganic ions. In this case, the plants adapt to the prevailing conditions, to maintain the osmotic potential gradient and the turgescence of the cells as close to the adequate levels as possible (Pereira et al., 2012).

According to Carvalho (2005), S. parahyba has been identified as a more drought-tolerant alternative than S. parahyba var. amazonicum (paricá) and other species, but there are no studies to confirm this. Duarte et al. (2016) reported that $S$. parahyba var. amazonicum plants when submitted to water deficit, with subsequent water replenishment, showed reduction in the number of leaves, stem diameter, plant height, and, of course, total biomass, as response to maintain the internal water, indicating low ability to tolerate stress.

Thus, this study had objective of identifying the mechanism of response to water deficit in $S$. parahyba (guapuruvu) seedlings.

The experiment was conducted in a randomized block design with five different treatments (irrigated with 20, $40,60,80$ and $100 \%$ of the evapotranspiration) and four replications, in a greenhouse using eight-liter-pots. The soil was classified as dystrophic Red-Yellow latosol (Oxisol). The soil was sieved and complemented with $3 \mathrm{~g}$ of dolomitic limestone, in accordance with the chemical analysis results. It was incubated and irrigated for about 30 days. Later, fertilization was carried out using $3 \mathrm{~g}$ of urea, $2.5 \mathrm{~g}$ of triple superphosphate and $2.2 \mathrm{~g}$ of potassium chloride per $\mathrm{kg}$ soil. Before placing the pots in the greenhouse, they were filled, weighed, and standardized at $5.5 \mathrm{~kg}$ of soil.

The seeds came from the Aimex Laboratory of Seeds and Seedlings of the Amazon Forest Species. Dormancy break procedure was applied to the seeds, according to the methodology proposed by Duarte et al. (2016). Three seeds were sown in each pot and thinning was carried out 30 days after emergence (DAE). Later, at approximately $60 \mathrm{DAE}$, top dressing was applied with $2 \mathrm{~g}$ of the formulation fertilizer 10-25-15.

The experiment was installed in a greenhouse, in the Universidade Estadual de Goiás, with shade mesh cover protetor (50\% sunblock) and temperature of $27.8{ }^{\circ} \mathrm{C}$ (average). The plants were irrigated daily with only the amount of water corresponding to the maximum daily evapotranspiration capacity. Subsequently, at 90 DAE, the plants were subjected to ten days of water deficit, being irrigated with $20,40,60,80$ and $100 \%$ of evapotranspiration, for another ten days, similar to Duarte et al. (2016).

The growth variables (number of leaves - NL, plant height $-\mathrm{PH}$, stem diameter $-\mathrm{SD}$, total biomass - TB) and physiological variables (total daily transpiration - TDT, carotenoids - CAR, total chlorophyll - TC, relative water content - RWC) were analyzed according to Duarte et al. (2016). Data were subjected to analysis of variance and when significant we conducted the regression analysis $(\mathrm{p}<0.05)$, using SISVAR statistical software (Ferreira, 2014).

It can be observed in Figures 1 and 2 that there was a significant effect for most variables $(p<0.05)$, except for carotenoids, indicating that this variable was not influenced by water stress, even with different percentages of evapotranspiration. This probably occurred because the stress suffered was only for 10 days, with $20 \%$ replacements, which was not so drastic for the $S$. parahyba seedlings and also due to the shade effect caused by the cover protetor. According to Rodrigues et al. (2019), S. parahyba var. amazonicum irrigated every 8 days, do not differ from those irrigated every 2 days, under cover protetor ( $40 \%$ sunblock), 
which indicates that the plant tolerates this period well under shade effect.

We observed NL reduction, with stabilization between the percentages of 20 and $60 \%$, demonstrating a tolerance strategy to avoid water loss (Figure 1). Some authors report that in addition to avoiding water loss, this is a common reaction of plants when submitted to water deficiency. Due to the strong synthesis and greater sensitivity to ethylene, leaf abscission is stimulated (Chaves et al., 2004). Therefore, it is considered an early adaptive response to places where water restrictions occur.

The seedlings also showed a reduction of their height by approximately $12 \mathrm{~cm}$, between the maximum and minimum points, with a decrease of $2.4 \mathrm{~cm}$ for each evaluated irrigation rate (Figure 1). This may have occurred because the plant under stress reduced its development and invested most of the photoassimilates in maintaining the seedling to ensure survival. Nascimento et al. (2011) analyzed the growth of
Hymenaeae courbaril seedlings in the soil at different water levels $(100,75,50$ and $25 \%$ of field capacity). They showed that the plants under severe stress (25\% of the pot capacity), presented $42.2 \%$ reduction in height, result that is lower than what was observed in this study. Studies carried out by Silva et al. (2010) with young plants of mulungu (Erythrina velutina), using the same treatments and field capacity as Nascimento et al. (2011), presented reduction near 37 to $64 \%$ for 50 and $25 \%$ field capacity, respectively.

The lower development in $\mathrm{PH}, \mathrm{SD}$ and reduction of the NL and RWC caused the reduction of total biomass, which was approximately $5 \mathrm{~g}$ lower between evapotranspiration 20 and $100 \%$ (Figures 1 and 2). This can be explained by the reduction of the net photosynthesis rate and consequently, a lower production of carbohydrates, which may have led to a decrease in the biomass accumulation of the evaluated plants, as also by a lower capacity to maintain the water in the plants tissues (Taiz \& Zeiger, 2009).
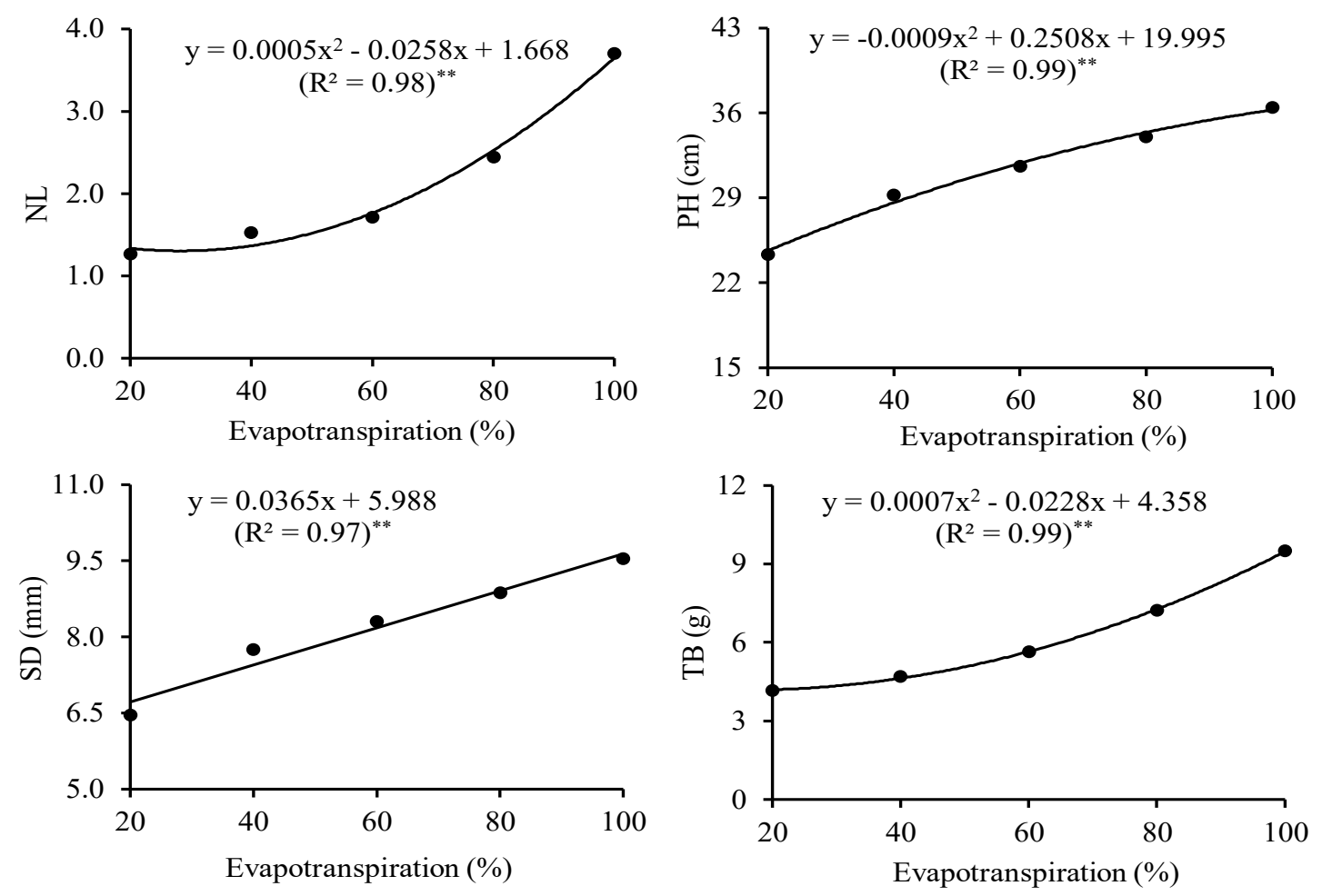

Figure 1. Number of leaves (NL), plant height (PH), stem diameter (SD) and total biomass (TB), evaluated in seedlings of Schizolobium parahyba (Vell.) Blake subjected to different rates of water supply (20, 40, 60, 80 and $100 \%$ of evapotranspiration), after water stress. 
The total daily transpiration presented a drastic reduction between 100 and $60 \%$, with stabilization after this point (Figure 2). It is possible to consider that between these points, the plants cannot effectively control the loss of water due to water stress, which is normally regulated by the stomatal opening. According to França et al. (2017), the reduction of transpiration in Calophyllum brasiliense (Cambess) seedlings occurs drastically with five days of water restriction and tends to reduce more after 15 days, indicating that several physiological processes are affected, such as, stomatal conductance, carotenoids, and supply of $\mathrm{CO}_{2}$ for photosynthesis. In this study, only the carotenoid content (Figure 2) did not present different results according to evapotranspiration rates.
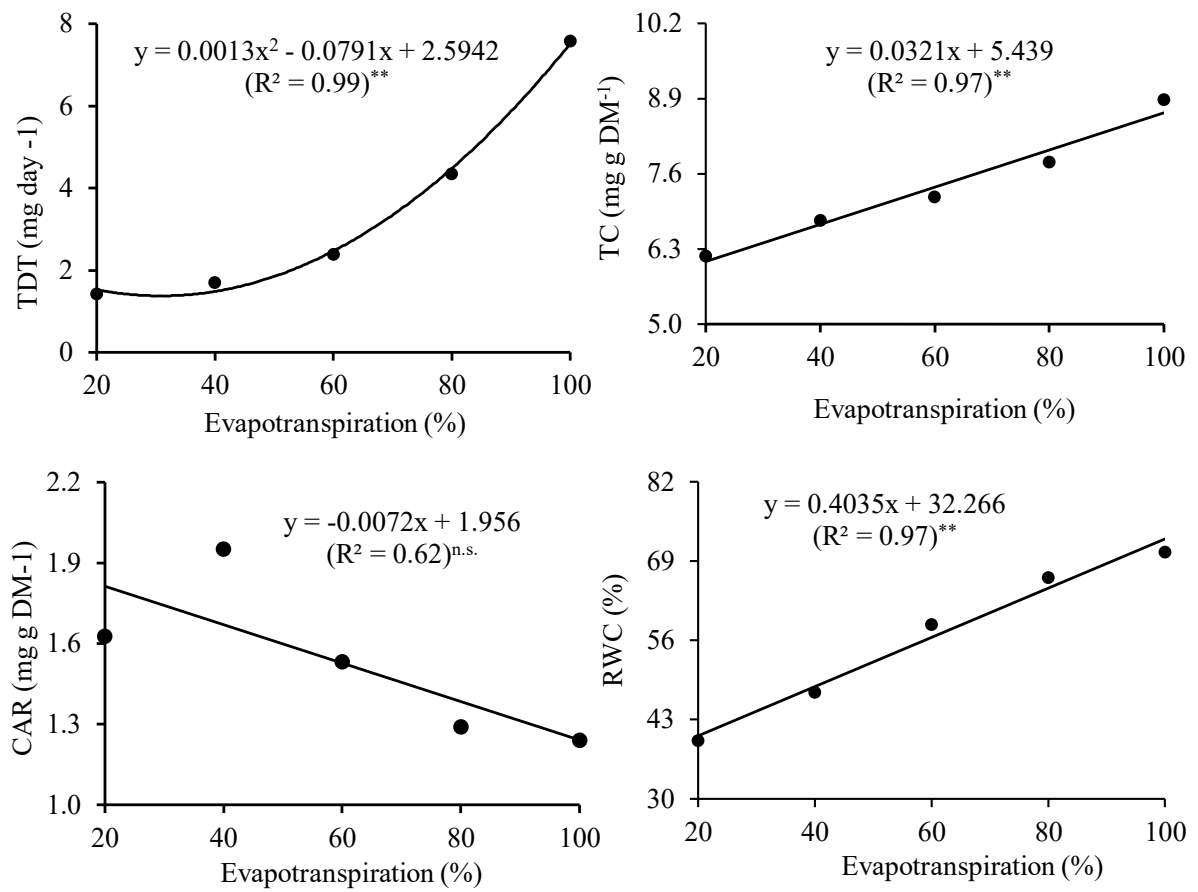

Figure 2. Total daily transpiration (TDT), total chlorophyll (TC), carotenoids (CAR) and relative water content (RWC) evaluated in seedlings of Schizolobium parahyba (Vell.) Blake subjected to different rates of water supply $(20,40,60,80$ and $100 \%$ of evapotranspiration), after water stress.

It was observed that the total chlorophyll and relative water content showed the same performance, suggesting an osmotic adjustment capacity of the plant (Figure 2). However, Duarte et al. (2016) reported that $S$. parahyba var. amazonicum under water deficit possibly increases the efficiency of the use of the water, although, in the studied specie, the carotenoids do not present an increasing behavior.

\section{Conclusions}

Schizolobium parahyba seedlings are partially tolerant to the water deficit and present dehydration delay as a strategy. The plants reduce growth and transpiration rate, presenting reduction of the number of leaves, height and stem diameter.

\section{Acknowledgments}

The authors would like to thank the Coordenação de Aperfeiçoamento de Pessoal de Nível Superior - Brasil (CAPES) - Finance Code - 001 and the Universidade Estadual de Goiás (UEG) for the PROBIP scholarship.

\section{References}

Athanázio-Heliodoro, J. C. et al. Properties of young guapuruvu (Schizolobium parahyba) Wood from a Forest Recovery Area. Floresta e Ambiente, v. 25, n. 3, 2018. http://doi.org/10.1590/21798087.036616 .

Bortoletto Júnior, G. \& Belini, U. L. Produção de lâminas e manufatura de compensados a partir da madeira de guapuruvu (Schizolobium parahyba Blake.) proveniente de um plantio misto de espécies nativas. Revista Cerne, v. 8, n. 2, p. 1-16, 2002. 
Carvalho, C. J. R. Respostas de plantas de Schizolobium amazonicum [S. parahyba var. amazonicum] e Schizolobium parahyba [Schizolobium parahybum] à deficiência hídrica. Revista Árvore, v. 29, n. 6, p. 907-914, 2005.

Chaves, J. H. et al. Seleção precoce de clones de eucalipto para ambientes com disponibilidade diferenciada de água no solo: relações hídricas de plantas em tubetes. Revista Árvore, v. 28, n. 3, p. 333341, 2004. http://doi.org/10.1590/S0100-67622004000300003.

Díaz-López, L. et al. Jatropha curcas seedlings show a water conservation strategy under drought conditions based on decreasing leaf growth and stomatal conductance. Agricultural Water Management, v. 105, n. 9, p. 48-56, 2012. http://doi.org/10.1016/j.agwat.2012.01.001.

Duarte, D. M. et al. Responses of paricá seedlings to water stress. Floresta, v. 46, n. 3, p. 405-412, 2016. http://doi.org/10.5380/ rf.v46i3.39529.

Ferreira, D. F. Sisvar: a Guide for its Bootstrap procedures in multiple comparisons. Ciência e Agrotecnologia, v. 38, n. 2. p. 109-112, 2014. http://doi.org/10.1590/S1413-70542014000200001.

França, P. H. T. et al. Análise fisiológica em mudas de guanandi (Calophyllum brasiliense Cambess) submetidas ao déficit hídrico. Agropecuária Científica no Semiárido, v. 13, n. 4, p. 264269, 2017. http://doi.org/10.30969/acsa.v13i4.886.

Guedes, J. D. A. \& Costa, F. R. Qualidade ambiental de dois reservatórios públicos na região do alto oeste potiguar ( $\mathrm{RN} /$ Brasil). Revista GeoInterações, v. 1, n. 1, p. 3-16, 2017.
Nascimento, H. H. C. et al. Análise do crescimento de mudas de jatobá (Hymenae courbaril L.) em diferentes níveis de água no solo. Revista Árvore, v. 35, n. 3, edição especial p. 617-626, 2011. http://doi.org/10.1590/S0100-67622011000400005.

Nisgoski, S. et al. Características anatômicas da madeira e índices de resistência do papel de Schizolobium parahyba (Vell.) Blake proveniente de plantio experimental. Scientia Forestalis, v. 40, n. 94, p. 203-211, 2012.

Pereira, J. W. de L. et al. Mudanças bioquímicas em genótipos de amendoim submetidos a déficit hídrico moderado. Revista Ciência Agronômica, v. 43, n. 4, p. 766-773, 2012.

Ramegowda, V. \& Senthil-Kumarb, M. The interactive effects of simultaneous biotic and abiotic stresses on plants: mechanistic understanding from drought and pathogen combination. Journal of Plant Physiology, v. 176, p. 47-54, 2015. http://doi.org/10.1016/j. jplph.2014.11.008.

Rossa, U. B. et al. Fertilização de liberação lenta no crescimento de mudas de paricá em viveiro. Pesquisa Florestal Brasileira, v. 33, n. 75, p. 227 - 234, 2013. http://doi.org/10.4336/2013.pfb.33.75.429.

Silva, E. C. et al. Growth evaluation and water relations of Erythrina velutina seedlings in response to drought stress. Brazilian Journal of Plant Physiology, v. 22, n. 4, p. 225-233, 2010. http://doi.org/10.1590/S1677-04202010000400002.

Sousa, D. B. et al. Paricá - Schizolobium amazonicum Huber ex Ducke. Informativo Técnico Rede de Sementes da Amazônia: 13. Manaus: Rede de Sementes da Amazônia, 2005.

Taiz, L. \& Zeiger, E. Fisiologia vegetal. 3.ed. Porto Alegre, RS: Artmed, 2009, 719 p. 